\section{Obituary}

Editor: Henry R. Rollin

DAvid IRWIN, formerly Physician Superintendent, St George's Hospital, Morpeth.

David Irwin died on 20 August 1986 at the age of 64. He had an outstanding school and undergraduate career. In 1944 he obtained a first class honours degree in physiology from Glasgow University and then graduated $\mathrm{MB}, \mathrm{ChB}$ in

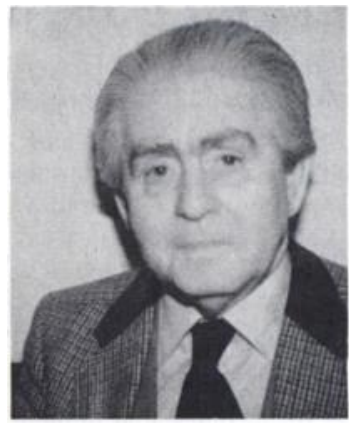
1947. Having decided on a career in psychiatry he took the DPM, London, in 1951 and in 1971 was elected a Foundation Member of the College and a Fellow in 1972.

He served at St George's Hospital, Morpeth, from 1955 when he was appointed Consultant Psychiatrist and Deputy Medical Superintendent, and then was promoted to the post of Physician Superintendent in 1962, a post he held until his retirement in 1983.

Dr Irwin gives as his hobbies: history of psychiatry, winemaking and, "As yet unfulfilled ambition to be a writer", a somewhat catholic spread of interests.

He is survived by his wife, Margaret, and three daughters, all of them graduates, and a son, a student at Oxford.

Walter Ritter von BaEYer, formerly Professor of Psychiatry, University of Heidelberg, Germany.

Professor Walter Ritter von Baeyer, who died in June 1987 at the age of 82, was one of the outstanding psychiatrists of his generation. Belonging to a distinguished academic family-his grandfather was a Nobel prize-winning chemist and his father a professor of orthopaedic surgery-he joined the renowned Heidelberg department of psychiatry in its heyday, only to witness its rapid decline following the accession to power of the National Socialists in 1933. From then until 1945 both his personal and professional life were clouded by political events. Nonetheless, despite his opposition to the regime he opted to stay in Germany. After World War II he resumed his career at Erlangen and Nuremberg before being appointed to the chair at Heidelberg which he occupied from 1955 until his retirement in 1972. There, in addition to his clinical and research activities, he devoted himself to the tasks of reconstruction and played a major role in rehabilitating the reputation of psychiatry in his own country. Although for some years he was victimised by a radical anarchist group, his national achievements were acknowledged by the awards of the Service Cross of the Republic and the Kraepelin Medal. He was recognised internationally by his election as vicepresident of the World Psychiatric Association and his membership of the Executive Committee of the World Federation of Mental Health. He became an honorary fellow of the Royal College of Psychiatrists in 1972. In his later years his advice was widely sought and he was closely associated with the creation of the Central Institute of Mental Health in Mannheim.

Von Baeyer's lifelong concerns with the underprivileged and suffering were most clearly illustrated by his wellknown study of the psychiatric sequelae of concentrationcamp survivors. His stated aim was to develop "a more strongly dynamic and anthropologically-oriented psychiatry, which uses psychotherapeutic and social methods more than has been the case hitherto". In this he was greatly assisted by the collaboration of his wife, a social scientist in her own right, who did much to support him. By his work and his example he contributed greatly to the revival of the best tradition of German psychiatry.

MS

\section{The deaths of the following have also been reported:}

FionA BroOK ANSON, Registrar, Springfield Hospital, London SW17.

Earle Franklin William Baker, Consultant Psychiatrist, Epsom District Hospital, Epsom, Surrey.

James Eric Alexander Bartlet, Consultant Psychiatrist, Coldeast Hospital, Southampton.

Alan Shannon Clark, formerly Consultant Psychiatrist, Enfield Child Guidance Clinic, Enfield, Middlesex

John Alastair DobBie, Consultant Psychiatrist, 52 Gurwood Street, Wagga Wagga, New South Wales, Australia.

Muhammad Wall Imam, Consultant Psychiatrist, St Margaret's Hospital, Birmingham.

ANDREW HAIN MoYes, formerly Medical Director, Brandon Mental Health Centre, Manitoba, Canada.

Sydney Maxwell Orelowitz, Consultant Psychiatrist, Warley Hospital, Brentwood, Essex.

Oliver Louis Zangwill, Professor, University of Cambridge, King's College, Cambridge.

\title{
Dr Morris Markowe
}

A memorial meeting for Dr Morris Markowe was held at Springfield Hospital, Tooting, London, SW17, on 30 September 1987. Those present were welcomed by Dr Julie Hollyman, a personal remembrance was given by Dr Peter Storey, and Dr Ian Lodge-Patch presented an appreciation entitled 'The Medical Administrator at Springfield and
Dr Markowe's special contribution.' A member of Dr Markowe's family read the Prayer said in a House of Mourning.

Dr Markowe was the first Registrar of the Royal College of Psychiatrists (see obituary in the Bulletin, October, 1987). 